\title{
Antioxidant and anti-inflammatory effects in lipopolysaccharide-induced THP-1 cells of coumarins from the bark of Hesperethusa crenulata R.
}

Seung-Su Lee ${ }^{1}$, Hyoung-Geun Kim', Eun-Ha Park², Kwang Joong Kim², Myun-Ho Bang ${ }^{3}$, Gayoung Kim', Hyeong-Ju Jeon ${ }^{4}$, Chung-Gi Lee ${ }^{5}$, Min-Chul Shin ${ }^{5}$, Dae-Ok Kim²,3 and Nam-In Baek ${ }^{1 *}$

\begin{abstract}
All parts of Thanakha (Hesperethusa crenulata R.) have been used as traditional skin care herbal material in Myanmar. In this study, coumarins from H. crenulata R. bark were isolated through solvent extraction, systematic solvent fractionation, and repeated column chromatography. Spectroscopic analyses using ESI-MS, 1D NMR (1H and 13C), 2D NMR (gHSQC and gHMBC), specific rotation, circular dichroism, and IR spectrometry revealed three coumarins 2R-7-hydroxy-8-(2,3-dihydroxy-3-methylbutyl)-coumarin (compound $\mathbf{1}$ ), peucedanol (compound $\mathbf{2}$ ), and methylpeucedanol (compound $\mathbf{3}$ ), which were first isolated from Thanakha tree. Antioxidant capacities of three coumarins decreased as follows: compound $\mathbf{2}>$ compound $\mathbf{3}>$ compound $\mathbf{1}$. Treatments of lipopolysaccharide-induced THP-1 human monocytic cells with compounds $\mathbf{2}$ and $\mathbf{3}$ at $378.8 \mu \mathrm{M}$ and $359.7 \mu \mathrm{M}$ inhibited tumor necrosis factor-a production by approximately $32.7 \%$ and $13.3 \%$, respectively, compared with the negative control. In summary, these results suggest that Thanakha bark extracts can be used as a potent antioxidant and anti-inflammatory source for cosmetic ingredients.
\end{abstract}

Keywords: Antioxidant capacity, Hesperethusa crenulata R., Methylpeucedanol, Peucedanol, Tumor necrosis factor-a

\section{Introduction}

Hesperethusa crenulata R. (Thanakha) is distributed in Southeast and South Asia, Myanmar, India, Malaysia, and Sri Lanka [1]. Thanakha paste made from the pulp of $H$. crenulata has been used for cosmetic purposes in Myanmar for over 2000 years. The traditional cream is applied to the face and arms for cooling and protection from sunburn [2]. For that reason, several cosmetic companies located at Myanmar have used Thanakha as an ingredient of cosmetic products $[1,3,4]$.

\footnotetext{
*Correspondence: nibaek@khu.ac.kr

${ }^{1}$ Graduate School of Biotechnology and Department of Oriental Medicinal Biotechnology, Kyung Hee University, Yongin 17104, Republic of Korea

Full list of author information is available at the end of the article
}

Characteristic features of $H$. crenulata physiology are aromatic volatile oil and a variety of secondary metabolites including coumarins, steroids, indoles, benzoquinones, and flavonoids $[1,5,6]$. Also, several studies have reported that $H$. crenulata extract exhibits various biological activities such as antioxidant, antiinflammatory, and anti-coagulant effects $[1,5,7,8]$. A monophenol peucedanol was previously reported to show free-radical-scavenging activity and inhibition of lipid peroxidation [9-11]. Peucedanol inhibited the activities of cholinesterases such as acetylcholinesterase and butyrylcholinesterase [11]. Lipopolysaccharides (LPS) is a component of Gram-negative bacteria that induces an inflammatory response to ultimately lead to production of cytokines, such as tumor necrosis factor (TNF)- $\alpha$ and interleukin (IL)-1. Coumarins isolated 
from the bark of $H$. crenulata $\mathrm{R}$. have been reported to inhibit TNF- $\alpha$ production by blocking activation of nuclear factor kappa $B$ and mitogen-activated protein kinases in LPS-activated THP-1 cells [12, 13].

This study was performed to discover principal components to play a role as functional cosmetic materials. The reason for focusing on coumarin compounds is that they have exellent anti-inflammatory effect reported as above. So skin improvement effect was also expected. And structural feature is as a benzopyrone derivative, coumarin has a heterocyclic C6-C3 structure of the coumarin nucleus (Fig. 1). It was two known coumarins, 2R-7-hydroxy-8-(2,3-dihydroxy-3-methylbutyl) coumarin (compound $\mathbf{1}$ ) and peucedanol (compound 2), along with a new coumarin methylpeucedanol (compound 3), were isolated from the bark of $H$. crenulata through solvent extraction, systematic solvent fractionation, and repeated column chromatography and identified using NMR spectroscopic analyses $\left({ }^{1} \mathrm{H}-\mathrm{NMR}\right.$, ${ }^{13} \mathrm{C}-\mathrm{NMR}$, Q-TOF LC/MS, and IR). All three coumarins were first isolated from the bark of Thanakha plant in this study.

Therefore, we aimed to evaluate antioxidant capacities of these three coumarins (compounds 1-3) isolated from the Thanakha bark in this study and their inhibitory effects on TNF- $\alpha$ production in LPS-induced THP-1 cells.

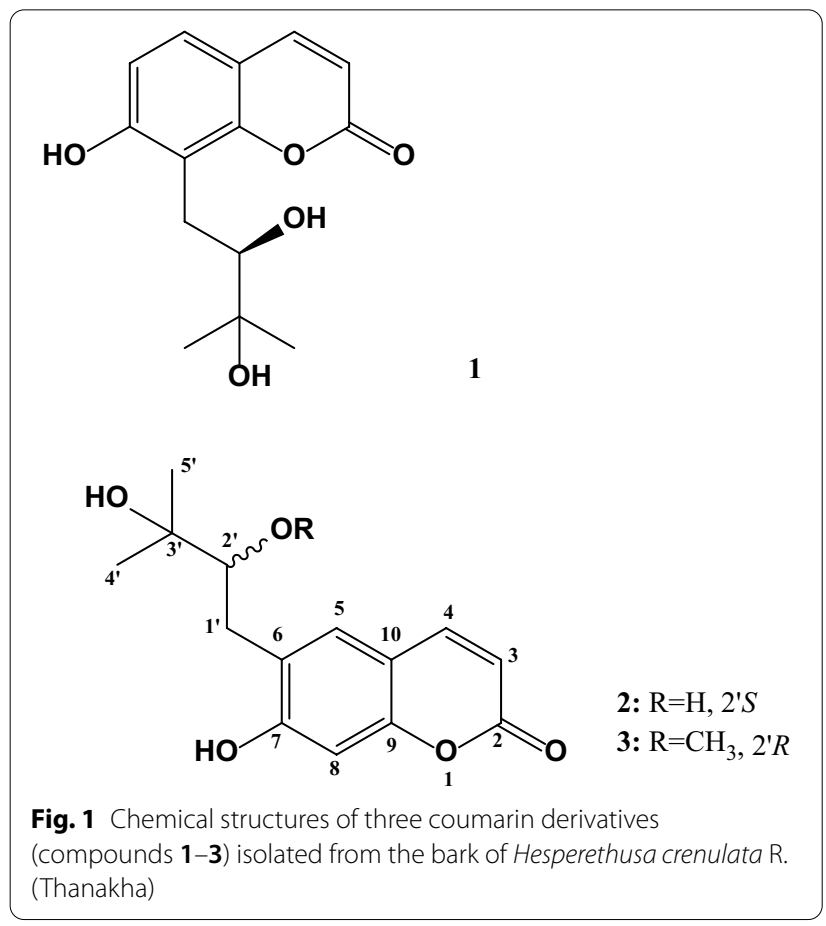

\section{Materials and methods \\ Reagents}

2,2'-zino-bis(3-ethylbenzothiazoline-6-sulfonic acid) diammonium salt (ABTS), 1,1-diphenyl-2-picrylhydrazyl (DPPH), 2,2'-azobis(2-amidinopropane) dihydrochloride (AAPH), vitamin $\mathrm{C}$, sodium acetate, 2,4,6,-tripyridyl-s-triazine (TPTZ), $\mathrm{HCl}, \mathrm{FeCl}_{3} \cdot 6 \mathrm{H}_{2} \mathrm{O}$, LPS from Escherichia coli O55:B5 were purchased from Sigma Chemical Co., LLC (St Louis, MO, USA). The three coumarins (compounds 1-3; purity $>95 \%$ ) used in this study were isolated from the ethyl acetate fraction of a $70 \%(\mathrm{v} / \mathrm{v})$ aqueous methanol extracts of $H$. crenulata $\mathrm{R}$. barks using column chromatography. Roswell Park Memorial Institute (RPMI)-1640 medium, penicillin/streptomycin, and fetal bovine serum (FBS) were purchased from Welgene Inc. (Gyeongsan, Republic of Korea). All other reagents used were of analytical or HPLC grade.

\section{Plant materials}

The barks of $H$. crenulata $\mathrm{R}$. were purchased from the market located at Taungbi Village, Old Bargan, Myanmar in June, 2018, and identified by Dae-Keun Kim, College of Pharmacy, Woosuk University, Jeonju, Korea. A voucher specimen (KHU0180607) was deposited at the Laboratory of Natural Products Chemistry, Kyung Hee University, Yongin, Republic of Korea.

\section{General experimental procedures}

Silica gel (230-400 mesh; Merck, Darmstadt, Germany) and Sephadex LH-20 (Merck) were used for column chromatography (c.c.). Preparative-liquid chromatography (prep-LC) (LC-Forte/R; YMC, Kyoto, Japan) was carried out using cartridge YMC-DispoPack (ODS25, $80 \mathrm{~g}$ and $120 \mathrm{~g}$; YMC). Thin-layer chromatography (TLC) analysis was performed using on a Kieselgel $60 \mathrm{~F}_{254}$ plate (Merck) and a RP-18 $\mathrm{F}_{254 \mathrm{~s}}$ plate (Merck), and detection was performed by a UV lamp at 254 and $365 \mathrm{~nm}$ and $10 \% \mathrm{H}_{2} \mathrm{SO}_{4}$ solution by spraying and heating. ${ }^{1} \mathrm{H}$ and ${ }^{13} \mathrm{C}$ NMR along with $2 \mathrm{D}$ NMR data were obtained on a Bruker AVANCE II $400\left({ }^{1} \mathrm{H}\right.$ NMR at $400 \mathrm{MHz}$ and ${ }^{13} \mathrm{C}$ NMR at $100 \mathrm{MHz}$ ) spectrometer (Bruker, Rheinstetten, Germany) in $\mathrm{CDCl}_{3}$ with TMS as internal standard. ESI/MS was obtained on a 6530 Accurate-Mass Q-TOF LC/MS (Agilent Technologies $\mathrm{GmbH}$, Waldbronn, Germany). IR spectra were obtained from a Perkin Elmer Spectrum One FT-IR spectrometer (Buckinghamshire, England). Curves of CD was recorded on a Jasco spectropolarimeter type J-715 at $21 \mathrm{C}$ (scan range, $200-400 \mathrm{~nm}$; and cell length, $0.1 \mathrm{~cm})$. 
Extraction and isolation of coumarins from the bark of $H$. crenulata

Dried bark powder $(5 \mathrm{~kg})$ was extracted overnight in $70 \%$ aqueous methanol ( $\mathrm{MeOH} ; 45 \mathrm{~L}$ ) at room temperature. The concentrated extract was poured into water $(3 \mathrm{~L})$ and extracted with ethyl acetate (EtOAc; $3 \mathrm{~L} \times 3$ ) and then $n$-butanol $(3 \mathrm{~L} \times 3)$ to give the EtOAc extract (140 g; HCE), $n$-butanol extract (45 g; HCB), and water extract ( $395 \mathrm{~g}$; HCW). The EtOAc extract was applied to silica gel c.c. $(5 \times 22 \mathrm{~cm})$ and eluted with $n$-hexaneEtOAc $(10: 1 \rightarrow 5: 1 \rightarrow 3: 1 \rightarrow 1: 1 ; 2 \mathrm{~L}$ of each $) \rightarrow \mathrm{CHCl}_{3}-$ $\mathrm{MeOH}(10: 1 \rightarrow 7: 1 \rightarrow 5: 1 \rightarrow 3: 1 \rightarrow 1: 1 ; 2 \quad \mathrm{~L}$ of each) while monitoring with TLC to produce 20 fractions (HCE-1 to HCE-20). Fraction HCE-9 $(940 \mathrm{mg}$ ) was submitted to $\mathrm{SiO}_{2}$ c.c. $(4 \mathrm{~cm} \times 20 \mathrm{~cm})$ and eluted with $n$-hexane-EtOAc $(4: 1 \rightarrow 3: 1 ; 6 \mathrm{~L}$ of both), yielding 11 fractions (HCE-9-1 to HCE-9-11) and a purified compound 2 (HCE-9-4, $31.5 \mathrm{mg}$, elution volume/total volume (Ve/Vt) 0.27-0.36, TLC (Kieselgel $60 \mathrm{~F}_{254}$ ) $\mathrm{R}_{\mathrm{f}} 0.51$, $n$-hexane-EtOAc $=1: 1)$. Fraction HCE-10 (4.8 g) was subjected to $\mathrm{SiO}_{2}$ c.c. $(4 \mathrm{~cm} \times 20 \mathrm{~cm})$ and eluted with $n$-hexane-EtOAc $(4: 1 ; 6 \mathrm{~L}$ ), yielding 12 fractions (HCE10-1 to HCE-10-12) along with a purified compound 1 (HCE-10-9, $137.6 \mathrm{mg}$, Ve/Vt 0.67-0.75, TLC (Kieselgel $\left.60 \mathrm{~F}_{254}\right) \mathrm{R}_{\mathrm{f}} 0.26, n$-hexane-EtOAc $\left.=1: 1\right)$. Fraction HCE12 (327 $\mathrm{mg}$ ) was applied to a preparative-LC cartridge: YMC-DispoPack AT (ODS-25, 80 g; and particle size, $25 \mu \mathrm{m})$ and eluted in $0.1 \%(\mathrm{v} / \mathrm{v})$ formic acid in water and $0.1 \%(\mathrm{v} / \mathrm{v})$ formic acid in acetonitrile $(7: 3)$ at a flow rate of $10 \mathrm{~mL} / \mathrm{min}$ using a UV detector at 254 and $356 \mathrm{~nm}$. Repeated collection of a peak at $29.5 \mathrm{~min}$ led to isolation of a purified compound 3 (49 mg). Chemical structures of three coumarin derivatives (compounds 1-3) from the Thanakha bark extracts are shown in Fig. 1.

\section{(2'R)-7-hydroxy-8-(2,3-dihydroxy-3-methylbutyl)-coumarin (compound 1)}

White amorphous powder $\left(\mathrm{CH}_{3} \mathrm{OH}\right) ;[\alpha]^{25}=+45^{\circ}$ $(c=0.5, \mathrm{MeOH})$; IR (KBr) $v_{\max } 3477,2950,1702$, $1629 \mathrm{~cm}^{-1}$; positive ESI-MS $\left.\mathrm{m} / z 247[\mathrm{M}-\mathrm{OH}+\mathrm{H}]\right]^{+} ;{ }^{1} \mathrm{H}-$ $\operatorname{NMR}\left(400 \mathrm{MHz}, \mathrm{CDCl}_{3}, \delta_{\mathrm{H}}\right) 7.64(1 \mathrm{H}, \mathrm{d}, J=9.1 \mathrm{~Hz}, \mathrm{H}-4)$, $7.28(1 \mathrm{H}, \mathrm{d}, J=8.1 \mathrm{~Hz}, \mathrm{H}-5), 6.76(1 \mathrm{H}, \mathrm{d}, J=8.1 \mathrm{~Hz}, \mathrm{H}-6)$, $6.21(1 \mathrm{H}, \mathrm{d}, J=9.1 \mathrm{~Hz}, \mathrm{H}-3), 4.80\left(1 \mathrm{H}, \mathrm{m}, \mathrm{H}-2^{\prime}\right), 3.32$ $\left(2 \mathrm{H}, \mathrm{m}, \mathrm{H}-1^{\prime}\right), 1.38,1.26$ (both $3 \mathrm{H}$, both $\mathrm{s}, \mathrm{H}-4^{\prime \prime}, \mathrm{H}-5^{\prime}$ ); ${ }^{13} \mathrm{C}-\mathrm{NMR}\left(100 \mathrm{MHz}, \mathrm{CDCl}_{3}, \delta_{\mathrm{C}}\right) 163.7$ (C-2), $160.9(\mathrm{C}-7)$, 151.3 (C-9), 143.8 (C-4), 128.7 (C-5), 114.0 (C-8), 113.1 (C-6), 112.6 (C-10), $106.6(\mathrm{C}-3), 91.3\left(\mathrm{C}-2^{\prime}\right), 71.7\left(\mathrm{C}-3^{\prime}\right)$, $27.5\left(\mathrm{C}-1^{\prime}\right), 25.9,24.0\left(\mathrm{C}-4^{\prime}, \mathrm{C}-5^{\prime}\right)$.

\section{Peucedanol (compound 2)}

Yellow amorphous powder $\left(\mathrm{CH}_{3} \mathrm{OH}\right) ;[\alpha]^{25}=-58.5(c$ 0.07, MeOH); IR (KBr) $v_{\max } 3495,3320,1715,1690 \mathrm{~cm}^{-1}$; positive ESI-MS $m / z 247 \quad[\mathrm{M}-\mathrm{OH}+\mathrm{H}]{ }^{+} ;{ }^{1} \mathrm{H}-\mathrm{NMR}$
Table $1{ }^{1} \mathrm{H}$ - and ${ }^{13} \mathrm{C}-\mathrm{NMR}$ spectral data of compounds $\mathbf{2}$ and $\mathbf{3}$ in $\mathrm{CDCl}_{3}$

\begin{tabular}{|c|c|c|c|c|}
\hline \multirow[t]{2}{*}{ No. } & \multicolumn{2}{|l|}{${ }^{1} \mathrm{H}-\mathrm{NMR}$} & \multicolumn{2}{|c|}{${ }^{13} \mathrm{C}-\mathrm{NMR}$} \\
\hline & 2 & 3 & 2 & 3 \\
\hline 2 & & & 163.8 & 160.7 \\
\hline 3 & $6.19(1 \mathrm{H}, \mathrm{d}, J=9.1)$ & $6.26(1 \mathrm{H}, \mathrm{d}, J=9.1)$ & 114.2 & 113.2 \\
\hline 4 & $7.84(1 \mathrm{H}, \mathrm{d}, J=9.1)$ & $7.64(1 \mathrm{H}, \mathrm{d}, J=9.1)$ & 146.3 & 143.3 \\
\hline 5 & $7.39(1 \mathrm{H}, \mathrm{s})$ & $7.33(1 \mathrm{H}, \mathrm{s})$ & 125.1 & 125.0 \\
\hline 6 & & & 127.4 & 129.5 \\
\hline 7 & & & 165.4 & 161.1 \\
\hline 8 & $6.71(1 \mathrm{H}, \mathrm{s})$ & $6.81(1 \mathrm{H}, \mathrm{s})$ & 98.3 & 98.9 \\
\hline 9 & & & 157.0 & 154.9 \\
\hline 10 & & & 112.3 & 112.1 \\
\hline $1 ' a$ & $3.25\left(2 \mathrm{H}, \mathrm{m}, \mathrm{H}-\mathrm{1}^{\prime}\right)$ & $3.02(1 \mathrm{H}, \mathrm{dd}, J=2.2,14.0)$ & 30.4 & 32.5 \\
\hline $1^{\prime} \mathrm{b}$ & $3.25\left(2 \mathrm{H}, \mathrm{m}, \mathrm{H}-\mathrm{1}^{\prime}\right)$ & $2.56(1 \mathrm{H}, \mathrm{dd}, J=10.5,14.0)$ & & \\
\hline $2^{\prime}$ & $4.76\left(1 \mathrm{H}, \mathrm{m}, \mathrm{H}-2^{\prime}\right)$ & $3.65(1 \mathrm{H}, \mathrm{br} . \mathrm{d}, J=10.5)$ & 92.6 & 77.6 \\
\hline $3^{\prime}$ & & & 72.4 & 72.8 \\
\hline $4^{\prime}-\mathrm{CH}_{3}$ & $1.30(3 \mathrm{H}, \mathrm{s})$ & $1.38(3 \mathrm{H}, \mathrm{s})$ & 25.5 & 26.3 \\
\hline $5^{\prime}-\mathrm{CH}_{3}$ & $1.24(3 \mathrm{H}, \mathrm{s})$ & $1.27(3 \mathrm{H}, \mathrm{s})$ & 25.4 & 23.6 \\
\hline $\mathrm{OCH}_{3}$ & & $3.92(3 \mathrm{H}, \mathrm{s})$ & & 56.0 \\
\hline
\end{tabular}

$\delta$ in ppm from TMS, $J$ value in $\mathrm{Hz}$

$\left(400 \mathrm{MHz}, \mathrm{CDCl}_{3}, \delta_{\mathrm{H}}\right)$ and ${ }^{13} \mathrm{C}-\mathrm{NMR}\left(100 \mathrm{MHz}, \mathrm{CDCl}_{3}\right.$, $\delta_{\mathrm{C}}$ ) see Table 1 .

\section{Methylpeucedanol (compound 3)}

Brown amorphous powder $\left(\mathrm{CH}_{3} \mathrm{OH}\right) ;[\alpha]^{25}{ }_{\mathrm{D}}=+81.0$ (c 0.01, MeOH); IR (KBr) $v_{\max } 3488,1708,1627 \mathrm{~cm}^{-1}$; ECD $(\mathrm{MeOH}) 333(\Delta \varepsilon-4.1)$; positive HRFABMS $\mathrm{m} / z$ $279.1223[\mathrm{M}+\mathrm{H}]^{+}\left(\right.$calcd for $\left.\mathrm{C}_{15} \mathrm{H}_{19} \mathrm{O}_{5}, 279.1228\right) ;{ }^{1} \mathrm{H}-$ NMR $\left(400 \mathrm{MHz}, \mathrm{CDCl}_{3}, \delta_{\mathrm{H}}\right)$ and ${ }^{13} \mathrm{C}-\mathrm{NMR}(100 \mathrm{MHz}$, $\mathrm{CDCl}_{3}, \delta_{\mathrm{C}}$ see Table 1 .

\section{Measurements of antioxidant capacities}

The antioxidant capacity of compounds 1-3 was assessed using the ABTS and FRAP (ferric reducing antioxidant power) assay and expressed in $\mathrm{mg}$ vitamin $C$ equivalents (VCE)/g of compound. The ABTS radical solution was adjusted to an absorbance of $0.650 \pm 0.020$ at $734 \mathrm{~nm}$ using a spectrophotometer (SPECTRONIC 200; Thermo Fisher Scientific Inc.). The reaction between ABTS radicals and the appropriately diluted samples was allowed to proceed at $37{ }^{\circ} \mathrm{C}$ for $10 \mathrm{~min}$, and then the decrease in absorbance of the resulting solution was measured at $734 \mathrm{~nm}$ using a spectrophotometer (SPECTRONIC 200; Thermo Fisher Scientific Inc.).

The antioxidant capacity using FRAP assay, FRAP reagent solution was prepared by mixing $0.3 \mathrm{M}$ sodium acetate buffer solution (pH 3.6), $10 \mathrm{mM} \mathrm{TPTZ}$ in $40 \mathrm{mM}$ $\mathrm{HCl}$, and $20 \mathrm{mM} \mathrm{FeCl}{ }_{3} \cdot 6 \mathrm{H}_{2} \mathrm{O}$ at a ratio of $10: 1: 1$. The reactions between the $950 \mu \mathrm{L}$ of FRAP reagent solution 
and $50 \mu \mathrm{L}$ of diluted samples were reacted for $30 \mathrm{~min}$ at room temperature, and then the absorbance at $593 \mathrm{~nm}$ was immediately measured by a spectrophotometer (SPECTRONIC 200; Thermo Fisher Scientific Inc.).

\section{Cell culture}

THP-1 cells, a human monocyte-like cell line, were maintained in RPMI-1640 medium supplemented with $10 \%$ heat-inactivated FBS, $100 \mu \mathrm{g} / \mathrm{ml}$ penicillin, and $100 \mu \mathrm{g} / \mathrm{ml}$ streptomycin at $37{ }^{\circ} \mathrm{C}$ in a humidified $5 \% \mathrm{CO}_{2}$ incubator. The cells were sub-cultured every 3-4 days and seeded onto 96-well plates. After incubation for $24 \mathrm{~h}$, cells were stimulated with Lactobacillus plantarum K8 lysate and/ or LPS.

\section{Enzyme-linked immunosorbent assay (ELISA)}

After cells were stimulated with compounds 1-3 and/or LPS, and culture supernatants were collected and used for the TNF- $\alpha$ ELISA assay. Human TNF- $\alpha$ capture antibody (R\&D \#MAB610) and human TNF- $\alpha$ biotinylated antibody ( $R \& D$ \#BAF210) were used according to the manufacturer's instructions.

\section{Statistical analysis}

All experiments were performed at least three times. Data are presented as the mean \pm standard deviation. Statistical analysis was performed using the Prism 5.0 software (GraphPad Software, USA). The significance of differences was assessed using an unpaired one- or twotailed Student's $t$ test. Differences were considered statistically significant when the $p$ value was $<0.05$.

\section{Results and discussion}

Identification of coumarins from the bark of $H$. crenulata R. The presence of coumarins in the EtOAc layer obtained from the $70 \%(\mathrm{v} / \mathrm{v})$ aqueous $\mathrm{MeOH}$ extract of $\mathrm{H}$. crenulata bark was confirmed by TLC, in which the spots showed UV absorption at 254 and $330 \mathrm{~nm}$ and an orange color under $10 \%(\mathrm{v} / \mathrm{v})$ sulfuric acid and heating. Repeated $\mathrm{SiO}_{2}$ and ODS column chromatography for EtOAc fraction led to isolation of a new (compound 3, yield: approximately $0.001 \%$ ) and two known (compounds 1, yield: approximately $0.003 \%$ and 2 , yield: approximately $0.001 \%$ ) coumarin derivatives were first isolated from the Thanakha bark.

The known coumarins were respectively identified as 2R-7-hydroxy-8-(2,3-dihydroxy-3-methylbutyl) coumarin (compound 1) and peucedanol (compound 2) based on spectroscopic data including NMR, MS, and specific rotation values and by comparing their spectroscopic data with those reported in the literature [11].

Compound 3 was obtained as a brown amorphous powder and was separated on TLC, sprayed with $10 \%$ (v/v) sulfuric acid, and heated to show an orange color. It showed absorbance bands due to hydroxy $\left(3475 \mathrm{~cm}^{-1}\right)$, conjugated ketone $\left(1635 \mathrm{~cm}^{-1}\right)$, double bond (1615, $\left.1605 \mathrm{~cm}^{-1}\right)$, and aromatic $\left(1515,1480 \mathrm{~cm}^{-1}\right)$ groups in the IR spectrum. The molecular weight was 278 from the molecular ion peak at $\mathrm{m} / z 279[\mathrm{M}+\mathrm{H}]^{+}$in positive ESI/MS. The ${ }^{1} \mathrm{H}-\mathrm{NMR}$ spectrum showed olefin methine proton signals at $\delta_{\mathrm{H}} 7.64(1 \mathrm{H}, \mathrm{d}, J=9.1 \mathrm{~Hz}, \mathrm{H}-4)$ and $\delta_{\mathrm{H}}$ $6.26(1 \mathrm{H}, \mathrm{d}, J=9.1 \mathrm{~Hz}, \mathrm{H}-3)$, which were attributed to one $\alpha$-pyrone, and olefin methine proton signals at $\delta_{\mathrm{H}}$ $7.33(1 \mathrm{H}, \mathrm{s}, \mathrm{H}-5)$ and $\delta_{\mathrm{H}} 6.81(1 \mathrm{H}, \mathrm{s}, \mathrm{H}-8)$ due to a 6,7 -disubstituted coumarin moiety. One oxygenated methine proton signal at $\delta_{\mathrm{H}} 3.65\left(1 \mathrm{H}\right.$, br.d, $\left.J=10.5, \mathrm{H}-2^{\prime}\right)$, one germinal methylene proton signal at $\delta_{\mathrm{H}} 3.02(1 \mathrm{H}, \mathrm{dd}, J=2.2$, $\left.14.0, \mathrm{H}-1 \mathrm{a}^{\prime}\right)$ and $\delta_{\mathrm{H}} 2.56\left(1 \mathrm{H}, \mathrm{dd}, J=2.2,14.0, \mathrm{H}-1 \mathrm{~b}^{\prime}\right)$, one methoxy signal at $\delta_{\mathrm{H}} 3.92\left(3 \mathrm{H}, \mathrm{s}, \mathrm{H}-\mathrm{OCH}_{3}\right)$, and two methyl proton signals at $\delta_{\mathrm{H}} 1.38\left(3 \mathrm{H}, \mathrm{s}, 4^{\prime}-\mathrm{CH}_{3}\right)$ and $\delta_{\mathrm{H}}$ $1.27\left(3 \mathrm{H}, \mathrm{s}, 5^{\prime}-\mathrm{CH}_{3}\right)$ were due to one oxygenated-isopentenyl unit. The ${ }^{13} \mathrm{C}-\mathrm{NMR}$ spectrum exhibited 15 carbon resonances including one methoxy $\delta_{\mathrm{C}} 56.0\left(\mathrm{OCH}_{3}\right)$ signal indicating compound 3 to be composed of one coumarin and one isoprene moiety. The multiplicity of each carbon was determined by a DEPT spectrum. The chemical shift of the signals in the ${ }^{13} \mathrm{C}$-NMR spectrum of compound 3 was similar to that of compound 2, peucedanol (see Table 1), with an additional methoxy moiety. The carbon signals due to one carbonyl at $\delta_{\mathrm{C}} 160.7$ (C-9); two oxygenated olefin quaternary carbons at $\delta_{\mathrm{C}} 161.1$ $(\mathrm{C}-7)$ and $\delta_{\mathrm{C}} 154.9$ (C-9); two olefin quaternary carbons at $\delta_{\mathrm{C}} 126.5(\mathrm{C}-6)$ and $\delta_{\mathrm{C}} 112.1(\mathrm{C}-10)$; and four olefin methines at $\delta_{\mathrm{C}} 143.3(\mathrm{C}-4), \delta_{\mathrm{C}} 125.0(\mathrm{C}-5), \delta_{\mathrm{C}} 113.2(\mathrm{C}-3)$, and $\delta_{\mathrm{C}} 98.9(\mathrm{C}-8)$ corresponded to the carbons of a coumarin moiety with one oxygenated and one carbonated substituent. In addition, carbon signals for one oxygenated quaternary methine at $\delta_{\mathrm{C}} 72.8\left(\mathrm{C}-3^{\prime}\right)$, one oxygenated methine at $\delta_{\mathrm{C}} 77.6\left(\mathrm{C}-2^{\prime}\right)$, one methylene at $\delta_{\mathrm{C}} 32.5$ $\left(\mathrm{C}-1^{\prime}\right)$, and two methyl at $\delta_{\mathrm{C}} 26.3\left(\mathrm{C}-\mathrm{CH}_{3}\right)$ and $\delta_{\mathrm{C}} 23.6$ $\left(\mathrm{C}-\mathrm{CH}_{3}\right)$ suggested the presence of one isopentenyl unit with two hydroxyl groups. Attachment of the methoxy moiety at C-2' was identified by the cross-peak between the oxygenated methine proton signal at $\delta_{\mathrm{H}} 3.65\left(\mathrm{H}-2^{\prime}\right)$ and the methoxy carbon signal at $\delta_{\mathrm{C}} 56.0$ in the $\mathrm{HMBC}$ spectrum. This was confirmed by HMBC correlations at $\delta_{\mathrm{H}} 3.65\left(\mathrm{H}-2^{\prime}\right) / \delta_{\mathrm{C}} 126.5(\mathrm{C}-6), \delta_{\mathrm{C}} 77.6\left(\mathrm{C}-2^{\prime}\right)$, and $\delta_{\mathrm{C}}$ $72.8\left(\mathrm{C}-3^{\prime}\right) ; \delta_{\mathrm{H}} 3.01\left(\mathrm{H}-1 \mathrm{a}^{\prime}\right)$ and at $\delta_{\mathrm{H}} 2.56\left(\mathrm{H}-1 \mathrm{~b}^{\prime}\right) / \delta_{\mathrm{C}} 77.6$ $\left(\mathrm{C}-2^{\prime}\right)$ and $\delta_{\mathrm{C}} 72.8\left(\mathrm{C}-3^{\prime}\right)$. The absolute configuration of $\mathrm{C}-2^{\prime}$ was determined to be $R$ from the positive cotton effect at $333 \mathrm{~nm}$. Its similar coumarin, (+)-peucedanol methyl ether, 6-[(2R)-2,3-dihydroxy-3-methylbutyl]7-methoxychromen-2-one, showed the positive cotton effect at $333 \mathrm{~nm}$. Therefore, the chemical structure of compound 3 was determined to be 6-[(2R)-3-hydroxy2-methyl-3-methylbutyl]-7-hydroxychromen-2-one, 
Table 2 Total phenolic and flavonoid content and antioxidant capacity of compounds $\mathbf{1}-\mathbf{3}$

\begin{tabular}{|c|c|c|}
\hline \multirow[t]{2}{*}{ Compound } & \multicolumn{2}{|c|}{$\begin{array}{l}\text { Antioxidant capacity (mg vitamin C } \\
\text { equiv./g DW') }\end{array}$} \\
\hline & $\mathrm{ABTS}^{\mathrm{b}}$ & FRAPC \\
\hline 1 & $4.58 \pm 0.19$ & n.d. ${ }^{d}$ \\
\hline 2 & $54.12 \pm 5.93$ & $5.52 \pm 0.91$ \\
\hline 3 & $40.15 \pm 0.36$ & $9.75 \pm 1.47$ \\
\hline \multicolumn{3}{|l|}{${ }^{a}$ Dry weight } \\
\hline \multicolumn{3}{|c|}{${ }^{\mathrm{b}} 2,2^{\prime}$-Azino-bis (3-ethylbenzothiazoline-6-sulfonic acid) radical scavenging assay } \\
\hline \multicolumn{3}{|c|}{${ }^{{ }^{C} \text { Ferric reducing antioxidant power assay }}$} \\
\hline \multicolumn{3}{|l|}{${ }^{\mathrm{d}}$ Not detected } \\
\hline
\end{tabular}

and was revealed to be a new coumarin, named methylpeucedanol.

Antioxidant capacity of three coumarins (compounds 1-3) The antioxidant capacities of compounds 1-3 are presented in Table 2. Antioxidant capacities measured by the ABTS radicals increased as follows: compound $\mathbf{1}<\mathrm{com}$ pound $3<$ compound 2 , whereas those measured by the FRAP assay increased as follows: compound $\mathbf{1}<\mathrm{com}-$ pound $\mathbf{2}<$ compound $\mathbf{3}$.

The extract of $H$. crenulata $\mathrm{R}$. has been reported to have antioxidant capacity due to the presence of phenolic compounds such as coumarins and flavones. Coumarins such as peucedanol and its glycoside in Peucedanum japonicum Thunb leave were previously reported to have DPPH-radical-scavenging activity and AAPH-induced lipid peroxidation $[9,14]$. Like those previous results, three coumarins tested in this study acted as antioxidants. These three coumarins, a group of monophenol isolated from Thanakha barks, have free hydroxyl $(-\mathrm{OH})$ group in the coumarin backbone, that can donate hydrogen or electron for the reduction of free radicals and transition metals.

\section{Anti-inflammatory effects of three coumarins isolated from the $H$. crenulata $R$. bark}

To test the anti-inflammatory effects of the coumarins isolated from the bark from $H$. crenulata R., TNF- $\alpha$ production was measured in LPS-stimulated THP-1 cells in this study. THP-1 cells were pre-treated with various coumarins for $18 \mathrm{~h}$ and re-treated with LPS (500 ng/ml) for $4 \mathrm{~h}$. The change in TNF- $\alpha$ production was not significant in the treatment with compound $\mathbf{1}$ compared with the DMSO control (Fig. 2). As shown in Fig. 2, compounds 2 and 3 at $378.8 \mu \mathrm{M}$ and $359.7 \mu \mathrm{M}$ inhibited the production of TNF- $\alpha$ in the culture media by $32.66 \pm 11.09 \%$

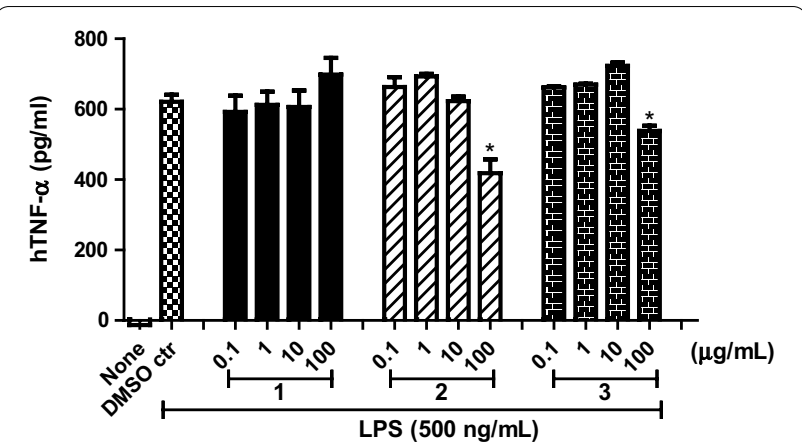

Fig. 2 Effects of three coumarin derivatives (compounds $\mathbf{1}-\mathbf{3}$ ) isolated from the bark of H. crenulata R. (Thanakha) on TNF-a production in lipopolysaccharide-induced THP-1 cells

and $13.33 \pm 4.21 \%$, respectively, suggesting that peucedanol and methylpeucedanol have the anti-inflammatory effects through reduced production of TNF- $\alpha$, one of pro-inflammatory cytokines.

The stem bark extracts from $H$. crenulata $\mathrm{R}$. has been reported to show potent anti-inflammatory effects in murine macrophage [1]. Many coumarins are previously reported to possess anti-inflammatory property. The two coumarins (compounds 2 and 3 ) showed anti-inflammatory effects via the inhibited production of TNF- $\alpha$ in human monocyte-like THP-1 cells. Peucedanol showed anti-inflammatory activity through the nitric oxide production inhibition in macrophage-like RAW 264.7 cells [10]. As compounds $\mathbf{2}$ and $\mathbf{3}$ had higher antioxidant capacity than compound $\mathbf{1}$ (Table 2), they were higher anti-inflammatory effects than compound 1 (Fig. 2), suggesting that antioxidant coumarin plays a role as an antiinflammatory agent.

In conclusion, we isolated and identified three coumarin derivatives (compound 1, 2R-7-hydroxy-8-(2,3-dihydroxy3-methylbutyl)-coumarin; compound 2, peucedanol; and compound 3, methylpeucedanol) from the bark of $H$. crenulata R. (Thanakha) in this study. These three compounds showed antioxidant capacities due to the presence of a free hydroxyl group on the coumarin backbone. Peucedanol and methylpeucedanol, a newly reported compound, had inhibitory effects on production of TNF- $\alpha$ in LPS-induced THP-1 cells. All parts of Thanakha (Hesperethusa crenulata R.) have been used as traditional skin care herbal material in Myanmar. The results of this study suggest that Thanakha bark extract is used as potent anti-inflammatory ingredients of functional foods and cosmetics. In addition to molecular biological mechanisms for the new substance (compound 3), in vivo anti-inflammatory animal studies will be needed in the future. 


\section{Supplementary Information}

The online version contains supplementary material available at https://doi. org/10.1186/s13765-021-00665-8.

Additional file 1. Raw data of NMR spectra for compound (1-3).

\section{Acknowledgements}

This work (Grant No. S2605014) was supported by project for Cooperative R \& $D$ between Industry, Academy, and Research Institute funded Korea Ministry of SMEs and Startups in 2018

\section{Authors' contributions}

S-SL, D-OK, and N-IB designed this study. S-SL, H-GK, E-HP, KJK, M-HB, GK, H-J, C-GL, and M-CS performed experiments and data curation. S-SL wrote original draft. D-OK supervised the project. D-OK and N-IB reviewed and edited the manuscript. All authors read and approved the final manuscript.

\section{Availability of data and materials}

The data and materials used in this study are available under permission from the corresponding author on reasonable request.

\section{Declarations}

\section{Competing interests}

The authors declare that they have no competing interests.

\section{Author details}

${ }^{1}$ Graduate School of Biotechnology and Department of Oriental Medicinal Biotechnology, Kyung Hee University, Yongin 17104, Republic of Korea. ${ }^{2}$ Department of Food Science and Biotechnology, Kyung Hee University, Yongin 17104, Republic of Korea. ${ }^{3}$ Skin Biotechnology Center, Kyung Hee University, Suwon 16229, Republic of Korea. ${ }^{4}$ Department of Food and Nutrition, Jangan University, Hwaseong 18331, Republic of Korea. ${ }^{5}$ Cytus H\&B, Cheongju 28160, Republic of Korea.

Received: 7 September 2021 Accepted: 12 December 2021

Published online: 22 December 2021

\section{References}

1. Wangthong S, Palaga T, Rengpipat S, Wanichwecharungruang SP, Chanchaisak P, Heinrich M (2010) Biological activities and safety of Thanaka (Hesperethusa crenulata) stem bark. J Ethnopharmacol 132:466-472

2. Mabberley DJ (1997) The plant-book: a portable dictionary of the vascular plants, 2nd edn. Cambridge University Press; p, New York, p 858

3. Seiverling EV, Trubiano JP, Williams JC, Ahrns HT, Craft DW, England MR (2017) Analysis of the antimicrobial properties of thanaka, a Burmese powder used to treat acne. J Biosci Med 5:1-6

4. Nayar MNS, Bhan MK (1972) Coumarins and other constituents of Hesperethusa crenulata. Phytochemistry 11:3331-3333

5. Annunziata F, Pinna C, Dallavalle S, Tamborini L, Pinto A (2020) An overview of coumarin as a versatile and readily accessible scaffold with broad-ranging biological activities. Int J Mol Sci 21:4618

6. Joo S-H, Lee S-C, Kim S-K (2004) UV absorbent, marmesin, from the bark of Thanakha, Hesperethusa crenulata L. J Plant Biol 47:163-165

7. Golfakhrabadi F, Abdollahi M, Ardakani MRS, Saeidnia S, Akbarzadeh T, Ahmadabadi AN et al (2014) Anticoagulant activity of isolated coumarins (suberosin and suberenol) and toxicity evaluation of Ferulago carduchorumin rats. Pharm Bio 52:1335-1340

8. Kistowska M, Meier B, Proust T, Feldmeyer L, Cozzio A, Kuendig T et al (2014) Propionibacterium acnes promotes Th17 and Th17/Th1 responses in acne patients. J Investig Dermatol 135:110-118

9. Hisamoto M, Kikuzaki H, Ohigashi H, Nakatani N (2003) Antioxidant compounds from the leaves of Peucedanum japonicum Thunb. J Agric Food Chem 51:5255-5261
10. Kim DH, Han CS, Kim GE, Kim JH, Kim SG, Kim HK et al (2009) Biolosical activities of isolated compounds from Peucedani Radix. Yakhak Hoeji 53:130-137

11. Karakaya S, Koca M, Sytar O, Dursunoglu B, Ozbek H, Duman H et al (2019) Antioxidant and anticholinesterase potential of Ferulago cassia with farther bio-guided isolation of active coumarin constituents. South Afr J Bot 121:536-542

12. Kim HG, Kim N-R, Gim MG, Lee JM, Lee SY, Ko MY et al (2008) Lipoteichoic acid isolated from Lactobacillus plantarum inhibits lipopolysaccharideinduced TNF-a production in THP-1 cells and endotoxin shock in mice. J Immunol 180:2553-2561

13. Chun JM, Lee AR, Kim HS, Lee AY, Gu GJ, Moon BC, Kwon BI (2018) Peucedanum japonicum extract attenuates allergic airway inflammation by inhibiting Th2 cell activation and production of pro-inflammatory mediators. J Ethnopharmacol 211:78-88

14. Singleton VL, Rossi JA Jr (1965) Colorimetry of total phenolics with phosphomolybdic-phosphotungstic acid reagents. Am J Enol Vitic 16:144-158

\section{Publisher's Note}

Springer Nature remains neutral with regard to jurisdictional claims in published maps and institutional affiliations.

\section{Submit your manuscript to a SpringerOpen ${ }^{\circ}$ journal and benefit from:}

- Convenient online submission

- Rigorous peer review

- Open access: articles freely available online

- High visibility within the field

- Retaining the copyright to your article

Submit your next manuscript at $\boldsymbol{\nabla}$ springeropen.com 